\title{
Inactivation of Escherichia coli O157:H7 and Listeria monocytogenes in biofilms by pulsed ultraviolet light
}

\author{
Nedra L. Montgomery ${ }^{1,3}$ and Pratik Banerjee ${ }^{1,2^{*}}$
}

\begin{abstract}
Background: The inactivation of biofilms formed by pathogenic bacteria on ready-to-eat and minimally processed fruits and vegetables by nonthermal processing methods is critical to ensure food safety. Pulsed ultraviolet (PUV) light has shown promise in the surface decontamination of liquid, powdered, and solid foods. In this study, the antimicrobial efficacy of PUV light treatment on nascent biofilms formed by Escherichia coli O157:H7 and Listeria monocytogenes on the surfaces of food packaging materials, such as low-density polyethylene (LDPE), and fresh produce, such as lettuce (Lactuca sativa) leaves, was investigated.

Results: The formation of biofilms on Romaine lettuce leaves and LDPE films was confirmed by crystal violet and Alcian blue staining methods. Inactivation of cells in the biofilm was determined by standard plating procedures, and by a luminescence-based bacterial cell viability assay. Upon PUV treatment of $10 \mathrm{~s}$ at two different light source to sample distances $(4.5$ and $8.8 \mathrm{~cm}$ ), viable cell counts of L. monocytogenes and E. coli O157:H7 in biofilms on the lettuce surface were reduced by $0.6-2.2 \log C F U \mathrm{~mL}^{-1}$ and $1.1-3.8 \mathrm{log} C F U \mathrm{~mL}^{-1}$, respectively. On the LDPE surface, the efficiency of inactivation of biofilm-encased cells was slightly higher. The maximum values for microbial reduction on LDPE were $2.7 \mathrm{log} C F U \mathrm{~mL}^{-1}$ and $3.9 \mathrm{log}$ CFU mL ${ }^{-1}$ for L. monocytogenes and E. coli O157:H7, respectively. Increasing the duration of PUV light exposure resulted in a significant $(P<0.05)$ reduction in biofilm formation by both organisms. The results also revealed that PUV treatment was more effective at reducing E. coli biofilms compared with Listeria biofilms. A moderate increase in temperature $\left(\sim 7-15^{\circ} \mathrm{C}\right)$ was observed for both test materials.
\end{abstract}

Conclusions: PUV is an effective nonthermal intervention method for surface decontamination of E. coli O157:H7 and L. monocytogenes on fresh produce and packaging materials.

Keywords: Escherichia coli O157:H7, Listeria monocytogenes, Biofilms, Pulsed ultraviolet (PUV) light, Microbial inactivation, Lettuce, Low-density polyethylene (LDPE)

\section{Background}

The contamination and persistence of pathogenic bacteria in certain fresh produce, including ready-to-eat products, have become an emerging concern in recent years. Minimally processed, ready-to-eat fruits and vegetables may contain human pathogens among their microflora owing to contamination at some point in the process

\footnotetext{
*Correspondence: pbnerjee@memphis.edu

${ }^{2}$ Division of Epidemiology, Biostatistics, and Environmental Health Science, School of Public Health, The University of Memphis, Memphis, TN 38152, USA

Full list of author information is available at the end of the article
}

from cultivation to consumption. Microbial contamination of fruits and vegetables may occur on the surface or may become internalized through cuts or crevices on the produce [1]. The presence of viable human pathogens in ready-to-eat fresh produce poses a significant food safety risk to consumers. Decontamination of fresh produce presents a challenge for the food processing industry as ready-to-eat fresh produce cannot be treated with heat (thermal processing). Nonthermal processes such as washing with aqueous sanitizer/antimicrobial agents (hypochlorite, peroxyacetic acid, hydrogen peroxide, trisodium phosphate, organic acids) [2, 3], gaseous antimicrobial treatments (ozone, chlorine dioxide) [3, 4], and 
some physical methods (such as gamma-irradiation) [5] have been employed to reduce the pathogen load on fresh produce. Among these nonthermal processing methods, the application of pulsed ultraviolet (PUV) light or pulsed-light for microbial decontamination of food surfaces, powders and liquid foods is well documented [6-13]. The US Food and Drug Administration approves certain applications of pulsed light for surface microbiological control of food products and food production environments $[14,15]$. This method, or variations on it, are also approved for the microbial inactivation of food contact surfaces, packaging materials, and medical devices in the European Union, Canada, and some other nations [14].

PUV irradiation is broad spectrum light with wavelengths ranging from ultraviolet to infrared (including UV-A, UV-B, UV-C, visible, and infrared wavelengths, spanning 200-1,100 nm) in which light-pulses are delivered at short durations (micro- to milliseconds) [13, 16, 17]. The high efficacy of pulsed-light is due to the higher amount of energy accumulation compared with continuous light that instantaneously discharges energy on its target. The energy distributed by the UV light source inactivates microorganisms by destroying DNA, thus providing a higher degree of decontamination, sanitation, and sterilization [18]. PUV is considered a nonthermal and nonchemical process when processing times are short; i.e., light energy is administered for a fraction of a second (milli- to microsecond) [17, 19]. Moreover, pulsed administration of UV-light is thousands of times more efficient at decontamination than continuous administration of UV-light $[13,17]$. PUV light-induced inactivation of microorganisms occurs owing to a combination of photochemical, photothermal, and photophysical mechanisms [14, 16, 17, 20]. Photochemical inactivation resembles the inactivation mechanism of UV-C (200$280 \mathrm{~nm}$ ) [11]. The photochemical effect alters the chemical structure of DNA by forming a thymine-thymine dimmer, preventing replication, and resulting in irreversible cellular injury and death $[16,20]$. Depending on the food matrix, light penetration of microbial cells can result in vapors originating from cellular water sources. Osmotic imbalances can also occur owing to absorption that result in cytoplasmic shrinkage and cell rupture. Photophysical effects can cause direct damage to the cells causing leakage of cellular materials $[11,14,16,20]$. PUV light has been shown to be an effective process for decontamination (of microbes or allergens) of many food products such as milk [13, 21], juice [22], spices [7], semi solid-foods such as liquid peanut butter [23], shrimps [17], shelled eggs [24], and meat [19, 25]. As a nonthermal post-harvest intervention method, PUV treatment is reported to be effective at reducing microbial loads on fruits and vegetables [26-28].

Researchers have shown that a low frequency pulsed light, UV-A light emitting diodes (UVA-LED), when administered to biofilms at 5- to 60-min pulses was more effective than 2.5- to 30-min UV exposure in continuous mode [29]. The PUV-mediated inactivation of microorganisms on small fruit surfaces has been reported [27]. Furthermore, the effectiveness of PUV at inactivating Escherichia coli [30], Salmonella [27], and Listeria monocytogenes [8] has been demonstrated. Previous studies have shown that PUV at low frequency is germicidal, and effective against harmful bacterial pathogens that are capable of forming biofilms [29]. However, to date, no studies have reported the effectiveness of PUV exposure on biofilms present on the surface of fresh produce and food packaging materials. In the current study, it is hypothesized that PUV will be effective in reducing surface contamination on fresh produce by reducing the numbers of viable cells in biofilms. To test this hypothesis, the effects of PUV process variables (such as time of exposure and distance from the strobe) were evaluated in the inactivation of biofilms formed by selected pathogens (L. monocytogenes and E. coli O157:H7) on a model leafy green produce (lettuce) and food contact system [low-density polyethylene (LDPE) packaging film].

\section{Results and discussion}

\section{Formation of biofilms on test surfaces}

The formation of biofilms on model surfaces (plastic petri dishes), Romaine lettuce, and packaging materials (LDPE bags) was evaluated qualitatively using crystal violet and Alcian blue staining methods, as described previously [31, 32]. The staining methods coupled with light microscopy provided direct evidence of biofilm formation by E. coli O157:H7 and L. monocytogenes on the test substrates mentioned above (data not shown). The results of in vitro microtiter plate-based biofilm formation assays of the two test pathogens at two different time points $\left(24\right.$ and $48 \mathrm{~h}$, at $30^{\circ} \mathrm{C}$ ) are presented in Figure 1. At $48 \mathrm{~h}$ of incubation, the degree of biofilm formation was significantly higher $(P<0.05)$ than at $24 \mathrm{~h}$ incubation for both pathogens. The OD value for E. coli $\mathrm{O} 157: \mathrm{H} 7$ at $48 \mathrm{~h}$ was $0.84 \pm 0.09$, compared with $0.28 \pm 0.02$ at $24 \mathrm{~h}$. For L. monocytogenes, the $\mathrm{OD}$ values at 24 and $48 \mathrm{~h}$ incubation (a measure of biofilm formation) were $0.21 \pm 0.02$ and $0.81 \pm 0.05$, respectively. It is apparent from the in vitro biofilm formation assays that the biofilm-forming microbial population increased over time at the test temperature, which is in agreement with several previous studies [31, 33-35]. 


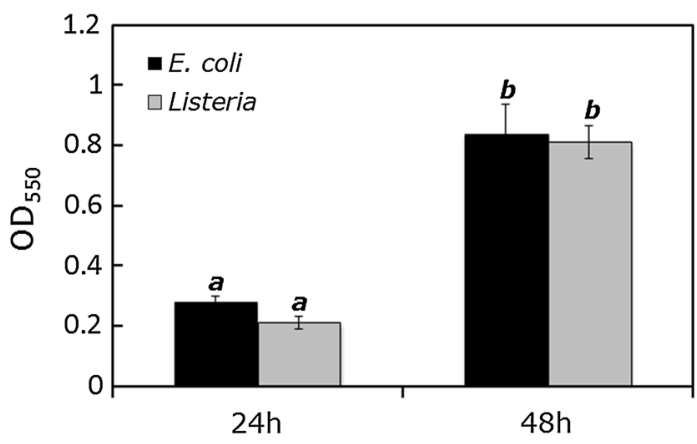

Figure 1 Microtiter plate-based in vitro biofilm formation assay of E. coli and L. monocytogenes. The formation of biofilm (at 24 and $48 \mathrm{~h}$ post-inoculation, at $30^{\circ} \mathrm{C}$ ) was measured by optical density readings at $550 \mathrm{~nm}$. Values are presented as the mean \pm SE of three experiments, repeated eight times. Columns mean, bars SE. Columns with different letters indicate significant differences $(P<0.05)$.

Microbial inactivation as a result of PUV light treatment The inactivation of test microorganisms as a result of PUV-light treatment was evaluated by two different quantitative methods: plating on selective agar plates and an ATP luminescence-based assay.

\section{Inactivation as enumerated by selective plating}

E. coli and L. monocytogenes cells in biofilm on the surfaces of lettuce and LDPE film pieces were treated with PUV-light at fluencies of 0.43 and $0.30 \mathrm{~J} \mathrm{~cm}^{-2}$ per pulse, which corresponded to 4.5 and $8.8 \mathrm{~cm}$ from the UV light source. The number of viable cells of $E$. coli and $L$. monocytogenes on lettuce biofilms (formed in 24 or $48 \mathrm{~h}$ ) post-PUV treatment at different exposure times to sample distances was determined by selective plating, as depicted in Figure 2A, B. A longer PUV exposure time to shorter sample to UV light source distance $(20 \mathrm{~s}-4.5 \mathrm{~cm})$ resulted in a significant reduction in viable cell counts in biofilms formed by both of the test pathogens on lettuce leaves when compared with a shorter exposure time to longer light source distance $(10 \mathrm{~s}-8.8 \mathrm{~cm})$. PUV treatment of lettuce leaves (with 24-h E. coli biofilms) for $10 \mathrm{~s}$ at 4.5 and $8.8 \mathrm{~cm}$ distances from the light source resulted in a $2.5 \log \mathrm{CFU} \mathrm{mL} \mathrm{mL}^{-1}$ and $1.4 \log \mathrm{CFU} \mathrm{mL}-1$ reduction of viable cells, respectively, compared with the no treatment controls. Inactivation of the same 24-h $E$. coli biofilms on lettuce leaves led to a greater reduction $(P<0.05)$ in viable cells to $3.9 \log C F U \mathrm{~mL}^{-1}$ (for $4.5 \mathrm{~cm}$ distance) and $3.1 \log$ CFU mL ${ }^{-1}$ (for $8.8 \mathrm{~cm}$ distance) when the PUV exposure time was increased to $20 \mathrm{~s}$ (Figure 2A).
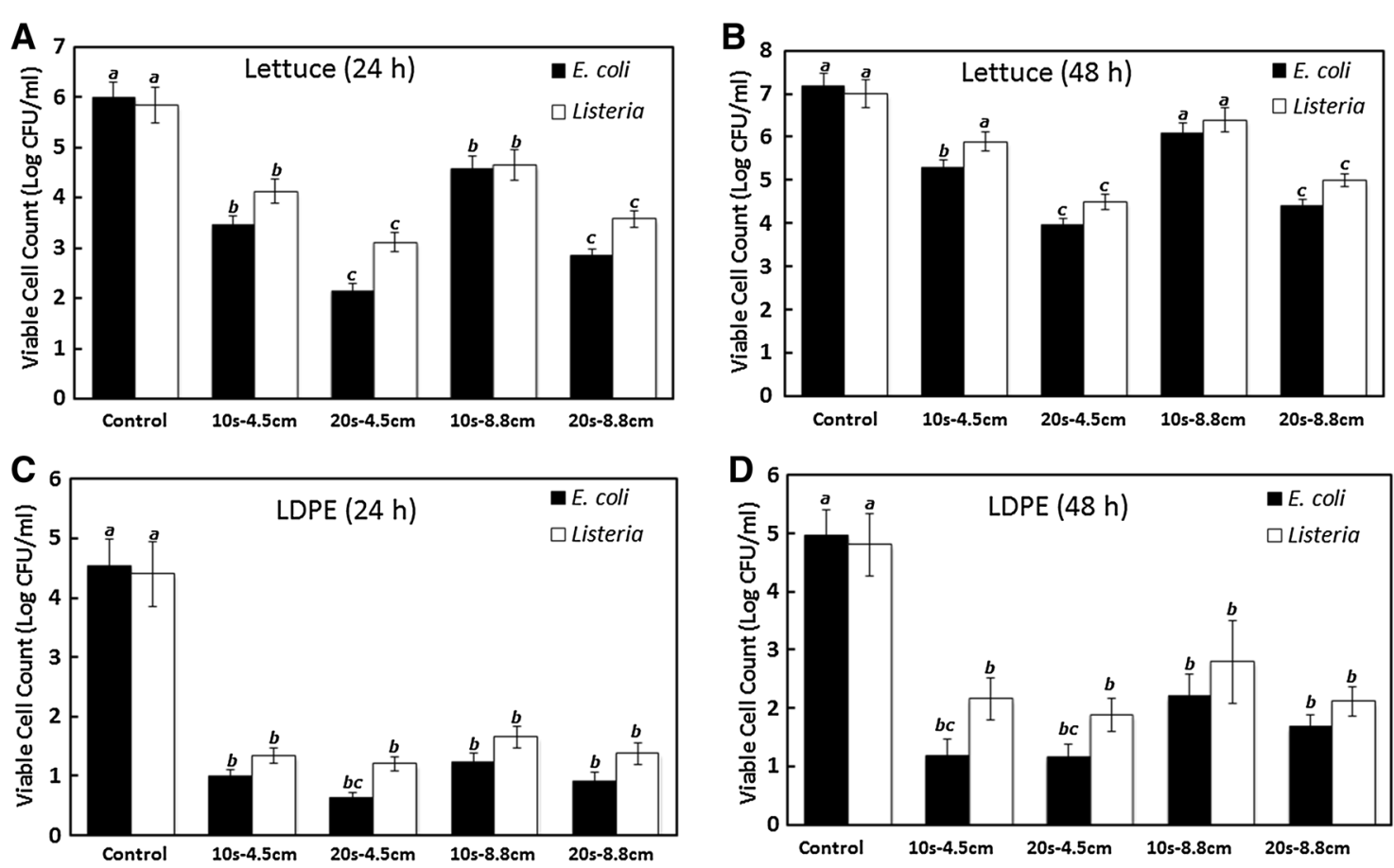

Figure 2 Survival of E. coli and L. monocytogenes in biofilms after PUV-light treatment. PUV-light treatment was performed under different exposure conditions, i.e., different times (in s) and distances (in $\mathrm{cm}$ ) from the UV source to the samples. A Lettuce leaves incubated at $30^{\circ} \mathrm{C}$ for $24 \mathrm{~h}$; $\mathbf{B}$ lettuce leaves incubated at $30^{\circ} \mathrm{C}$ for $48 \mathrm{~h}$; C LDPE films incubated at $30^{\circ} \mathrm{C}$ for $24 \mathrm{~h}$; $\mathbf{D}$ LDPE films incubated at $30^{\circ} \mathrm{C}$ for $48 \mathrm{~h}$. Values are presented as the mean \pm SE of two experiments performed in triplicate. Columns mean, bars SE. Columns labeled with different letters indicate significant differences $(P<0.05)$. 
The PUV-mediated reduction in viable counts for 48-h $E$. coli biofilms on lettuce leaves showed a similar trend, with the $10 \mathrm{~s}-4.5 \mathrm{~cm}$ and $20 \mathrm{~s}-4.5 \mathrm{~cm}$ treatments resulting in a reduction in viable cells of $1.9 \log \mathrm{CFU} \mathrm{mL} \mathrm{m}^{-1}$ and 3.2 $\log \mathrm{CFU} \mathrm{mL} \mathrm{m}^{-1}$, respectively. For longer $(8.8 \mathrm{~cm})$ sampleUV light source distances, the reduction in viable cells was lessened to $1.1 \log \mathrm{CFU} \mathrm{mL} \mathrm{m}^{-1}$ (for $10 \mathrm{~s}$ treatment) and $2.78 \log \mathrm{CFU} \mathrm{mL} \mathrm{m}^{-1}$ (for $20 \mathrm{~s}$ treatment). In general, it was also observed that the biofilm formed by E. coli on lettuce leaves over a period of $48 \mathrm{~h}$ was more resistant to PUV light treatment compared with biofilms formed over $24 \mathrm{~h}$ (Figure 2A, B). Romaine leaf samples containing 24 or $48 \mathrm{~h} \mathrm{~L}$. monocytogenes biofilms treated with PUV light for $20 \mathrm{~s}-4.5 \mathrm{~cm}$ showed significant (2.7- and $\left.2.5-\log C F U \mathrm{~mL}^{-1}\right)$ reductions in viable cell counts compared with the no-PUV controls (Figure 2A, B) $(P<0.05)$. For a PUV light treatment of $10 \mathrm{~s}$ at a distance of $8.8 \mathrm{~cm}$, the inactivation of $L$. monocytogenes biofilms resulted in reductions of viable cells of $1.19 \log \mathrm{CFU} \mathrm{mL} \mathrm{mL}^{-1}$ (for $24 \mathrm{~h}$ biofilms) and $0.6 \log \mathrm{CFU} \mathrm{mL} \mathrm{m}^{-1}$ (for $48 \mathrm{~h}$ biofilms); these values were not significant when compared to PUV untreated controls $(P>0.05)$. Samples treated at $8.8 \mathrm{~cm}$ for $20 \mathrm{~s}$, however, resulted in significantly reduced counts of viable Listeria cells and the inactivation of 2.25 and $2.01 \log$ CFU mL ${ }^{-1}$ from the 24 and $48 \mathrm{~h}$ biofilms, respectively, compared with the control (no PUV) $(P<0.05)$. In all of the above cases, the extent of inactivation was calculated by subtracting the viable cell count of a particular treatment from the respective control value.

Pieces of LDPE film were used to mimic the food contact surface capable of harboring bacterial biofilms. These LDPE pieces were optically transparent and showed higher levels of PUV-light mediated inactivation compared with Romaine lettuce leaves. However, the overall pattern of inactivation of viable cells in biofilms for the test pathogens was similar to that seen with Romaine leaves. For the treatment of $10 \mathrm{~s}$ at a distance of $8.8 \mathrm{~cm}$, the recorded inactivation values for $E$. coli $\mathrm{O} 157: \mathrm{H} 7$ were 3.29 and $2.76 \log \mathrm{CFU} \mathrm{mL} \mathrm{mL}^{-1}$ for the 24 and $48 \mathrm{~h}$ biofilms, respectively. When the treatment time was increased to $20 \mathrm{~s}$ (for $8.8 \mathrm{~cm}$ distance), the maximum E. coli O157:H7 inactivation was found to be 3.9 $\log$ CFU mL ${ }^{-1}$ (Figure 2C). Listeria biofilms offered more resistance to PUV-mediated inactivation on LDPE films compared with E. coli biofilms. For a PUV treatment of $10 \mathrm{~s}-8.8 \mathrm{~cm}$, Listeria inactivation values were found to be $2.3 \log$ CFU mL $\mathrm{mL}^{-1}(24 \mathrm{~h})$ and $1.9 \log \mathrm{CFU} \mathrm{mL} \mathrm{m}^{-1}(48 \mathrm{~h})$. For Listeria, the maximum inactivation was found to be $2.8 \log$ CFU mL ${ }^{-1}$ (PUV light treatment of $20 \mathrm{~s}-4.5 \mathrm{~cm}$ ) (Figure 2C, D). Again, the inactivation values reported above were calculated by subtracting the viable cell counts after a particular treatment from the respective control values.

\section{Inactivation as enumerated by a luminescence-based quantitative assay}

The effect of PUV treatment on the viability of microorganisms forming biofilms was evaluated by measuring the ATP released from bacteria using a BacTiter-Glo ${ }^{\text {тm }}$ Microbial Cell Viability Assay Kit (Promega). The results from this culture independent assay (Table 1) were used to confirm the results obtained by direct microbial plating. A PUV light treatment of $20 \mathrm{~s}-4.5 \mathrm{~cm}$ on E. coli O157:H7 biofilms on lettuce resulted in the lowest ATP bioluminescence values (i.e., lowest viability) for both of the time points resulting in approximately $1.2 \mathrm{log}$ relative luminescence units (RLU) $\mathrm{mL}^{-1}$ (at $24 \mathrm{~h}$ ) and $1.7 \log \mathrm{RLU}$ $\mathrm{mL}^{-1}$ (at 48 h). For all E. coli O157:H7 biofilms formed on lettuce leaves, PUV treatments showed significantly $(P<0.05)$ lower RLU values compared with the control (no PUV) (Table 1). However, for L. monocytogenes biofilms on lettuce, not all treatments showed significantly $(P<0.05)$ lower RLU values compared with the control (no PUV). For Listeria on lettuce, PUV treatment of $20 \mathrm{~s}-4.5 \mathrm{~cm}$ resulted in the highest inactivation yielding lower approximate ATP bioluminescence values of 2.5 and $2.8 \log \mathrm{RLU} \mathrm{mL}^{-1}$ at 24 and $48 \mathrm{~h}$, respectively. Listeria biofilms showed resistance to the PUV treatment of $10 \mathrm{~s}-8.8 \mathrm{~cm}$, confirming the plating data, and indicating that the reduction in viable cells at this PUV light dosage was not significant $(P>0.05)$. For the PUV treatment of $10 \mathrm{~s}-8.8 \mathrm{~cm}$, the luminescence values were around $3.9 \log \mathrm{RLU} \mathrm{mL} \mathrm{m}^{-1}$ (for $24 \mathrm{~h}$, the corresponding control value was $\sim 4.8 \log \mathrm{RLU} \mathrm{mL} \mathrm{mL}^{-1}$ ) and $4.1 \log \mathrm{RLU} \mathrm{mL} \mathrm{m}^{-1}$ (for $48 \mathrm{~h}$, the corresponding control value was $\sim 4.7 \mathrm{log}$ RLU mL ${ }^{-1}$ ). For LDPE films, the PUV-mediated inactivation of both the test pathogens in biofilms was found to be significant $(P<0.05)$. For $E$. coli biofilms, the highest approximate ATP bioluminescence value was recorded as $1.65 \log \mathrm{RLU} \mathrm{mL} \mathrm{m}^{-1}$ (PUV dosage of $10 \mathrm{~s}-8.8 \mathrm{~cm}$ at $48 \mathrm{~h}$ ) while the lowest bioluminescence value was around 0.62 $\log \mathrm{RLU} \mathrm{mL} \mathrm{m}^{-1}$ (PUV dosage of $20 \mathrm{~s}-4.5 \mathrm{~cm}$ at $24 \mathrm{~h}$ ). A similar trend was observed for Listeria biofilms; however, the RLU values were higher than the $E$. coli values for each corresponding treatment point. For example, a PUV dosage of $10 \mathrm{~s}-8.8 \mathrm{~cm}$ at $48 \mathrm{~h}$ yielded an approximate bioluminescence value of $2.8 \log \mathrm{RLU} \mathrm{mL} \mathrm{m}^{-1}$ (highest for Listeria), and for PUV treatment of $20 \mathrm{~s}-4.5 \mathrm{~cm}$ at $24 \mathrm{~h}$ this value was $1.15 \pm 0.2 \log \mathrm{RLU} \mathrm{mL}^{-1}$ (lowest for Listeria). It is evident from these data that, upon PUV light treatment there was a higher population of surviving bacterial cells in Listeria biofilms than in E. coli biofilms.

The results from this study demonstrate that PUV-light treatment has microbicidal effects on biofilms formed by two major foodborne pathogens, E. coli and L. monocytogenes. Another significant observation is that the PUVtreatment groups, as they relate to leaf or LDPE surfaces, 
Table 1 Viability of biofilm-encased E. coli and L. monocytogenes (on lettuce or LDPE) after PUV treatment

\begin{tabular}{|c|c|c|c|c|c|}
\hline \multirow[t]{3}{*}{ Microorganism } & \multirow{3}{*}{$\begin{array}{l}\text { PUV-treatment [time }(\mathrm{s}) / \\
\text { distance }(\mathrm{cm})]\end{array}$} & \multicolumn{4}{|c|}{ Viable cell population ( $\log \mathrm{RLU} \mathrm{mL}^{-1}$ ) } \\
\hline & & \multicolumn{2}{|l|}{ Lettuce } & \multicolumn{2}{|l|}{ LDPE } \\
\hline & & $24 \mathrm{~h}$ & $48 \mathrm{~h}$ & $24 \mathrm{~h}$ & $48 \mathrm{~h}$ \\
\hline \multirow[t]{5}{*}{ E. coli O157:H7 } & Control (no PUV) & $4.50 \pm 0.34 \mathrm{~A}$ & $4.40 \pm 0.29 \mathrm{~A}$ & $4.53 \pm 0.35 \mathrm{~A}$ & $4.04 \pm 0.30 \mathrm{~A}$ \\
\hline & $10 \mathrm{~s}-4.5 \mathrm{~cm}$ & $1.97 \pm 0.22 C$ & $2.35 \pm 0.27 B$ & $0.99 \pm 0.17 \mathrm{~B}$ & $1.34 \pm 0.23 B$ \\
\hline & $20 \mathrm{~s}-4.5 \mathrm{~cm}$ & $1.22 \pm 0.20 C$ & $1.74 \pm 0.24 C$ & $0.62 \pm 0.15 C$ & $1.20 \pm 0.20 B$ \\
\hline & $10 \mathrm{~s}-8.8 \mathrm{~cm}$ & $2.61 \pm 0.31 \mathrm{~B}$ & $2.65 \pm 0.29 B$ & $1.23 \pm 0.24 B$ & $1.65 \pm 0.24 B$ \\
\hline & $20 \mathrm{~s}-8.8 \mathrm{~cm}$ & $1.62 \pm 0.25 C$ & $2.04 \pm 0.26 B$ & $0.90 \pm 0.16 \mathrm{~B}$ & $1.38 \pm 0.13 B$ \\
\hline \multirow[t]{5}{*}{ L. monocytogenes } & Control (no PUV) & $4.80 \pm 0.35 \mathrm{~A}$ & $4.70 \pm 0.46 \mathrm{~A}$ & $4.96 \pm 0.32 \mathrm{~A}$ & $4.71 \pm 0.36 \mathrm{~A}$ \\
\hline & $10 \mathrm{~s}-4.5 \mathrm{~cm}$ & $3.39 \pm 0.24 B$ & $3.78 \pm 0.37 B$ & $1.17 \pm 0.22 C$ & $2.15 \pm 0.31 \mathrm{~B}$ \\
\hline & $20 \mathrm{~s}-4.5 \mathrm{~cm}$ & $2.53 \pm 0.22 C$ & $2.88 \pm 0.33 B$ & $1.15 \pm 0.20 C$ & $1.88 \pm 0.33 C$ \\
\hline & $10 \mathrm{~s}-8.8 \mathrm{~cm}$ & $3.90 \pm 0.30 \mathrm{AB}$ & $4.10 \pm 0.40 \mathrm{~A}$ & $2.20 \pm 0.32 B$ & $2.80 \pm 0.41 \mathrm{~B}$ \\
\hline & $20 \mathrm{~s}-8.8 \mathrm{~cm}$ & $2.83 \pm 0.27 B$ & $3.19 \pm 0.36 B$ & $1.67 \pm 0.25 C$ & $2.11 \pm 0.36 \mathrm{~B}$ \\
\hline
\end{tabular}

PUV-light treatment was performed under four different exposure conditions, i.e., different times (in s) and distances (in $\mathrm{cm}$ ). Each treatment was replicated twice and assays were performed in triplicate. Values (mean $\pm \mathrm{SE}$ ) are given for each surface (lettuce or LDPE) and each incubation time (24 or $48 \mathrm{~h}$ post-inoculation), and different letters denote significant differences $(P<0.05)$.

exhibited differences in inactivation. The biofilm formed on the leaf surface showed less PUV-mediated inactivation compared with the biofilm formed on LDPE film (Table 1). This indicated that the surface on which the biofilm forms effects PUV-mediated inactivation. Obviously, the surface topographies and the composition of a lettuce leaf are quite different from that of LDPE film. Attachment of cells in so-called "shadows" or locations where PUV-light may not reach (like stomata or leaf cavities) could provide enhanced protection from interventions, as previously reported [36]. It is evident from the literature that the presence of organic materials may provide microbial cells with more resistance to UV-light mediated disinfection [37] or other chemical disinfectants [36], which may partially explain why bacterial cells attached to lettuce may exhibit higher resistance to PUV treatment. Moreover, PUV treatment is a light-mediated intervention; therefore, the optical transparency and reduced surface roughness of the packaging film may also effect inactivation, as previously reported [38].

In our experiments, L. monocytogenes cells in biofilms showed a relatively higher resistance to PUV-treatment compared with E. coli O157:H7 cells for both lettuce and LDPE surfaces. The enhanced resistance of biofilmforming Listeria (compared with E. coli) to different antimicrobial treatments, including pulsed-light has been reported by several earlier studies [36, 37, 39-41]. Ölmez and Temur (2010) reported a higher reduction of $E$. coli than Listeria on lettuce leaves as a result of chlorine and organic acid treatments [36]. The higher inactivation of $E$. coli was also reported when dip wash treatment with organic acids was applied to iceberg lettuce [42]. The precise mechanism responsible for the differential PUV-light mediated inactivation of $E$. coli O157:H7 (strain EDL933) and L. monocytogenes (strain V7) remains to be determined. However, it is evident in the literature that the relative interaction between antimicrobials with bacterial cells (either in planktonic or sessile form) is complex [35] and depends on several factors, including the antimicrobial used [43-45], surface type [46], and the bacterial strain [47-49]. It has also been reported that the robustness of biofilms formed by Gram-positive and Gramnegative bacteria may be attributed to cell wall structure, secreted compounds, and growth factors [50]. In Grampositive bacteria (such as Listeria) the peptidoglycan layer is thick compared with Gram-negative bacteria, this differential thickness in peptidoglycan may contribute to differences in PUV-mediated inactivation, as proposed previously [51]. Moreover, a thick peptidoglycan layer consists of more sugars and amino acids and secreted residues, potentially aiding the formation of a firmer biofilm $[50,52]$. However, no definite mechanistic explanation has been proposed to date for why PUV-treatment was less effective on biofilms formed by L. monocytogenes than E. coli O157:H7.

\section{Temperature profiles of PUV light treatment}

To assess the extent of heat generated by the PUV process, surface temperatures of the samples were recorded using an infrared thermometer. The temperatures at sample distances of 8.8 and $4.5 \mathrm{~cm}$ from the UV light source are given in Figure 3. The maximum surface temperature increase of $15.8 \pm 2.6^{\circ} \mathrm{C}$ was observed for a PUV dosage of $20 \mathrm{~s}-4.5 \mathrm{~cm}$ on lettuce, with a highest recorded temperature post-treatment of $42.1 \pm 2.5^{\circ} \mathrm{C}$. When the PUV light treatment was 

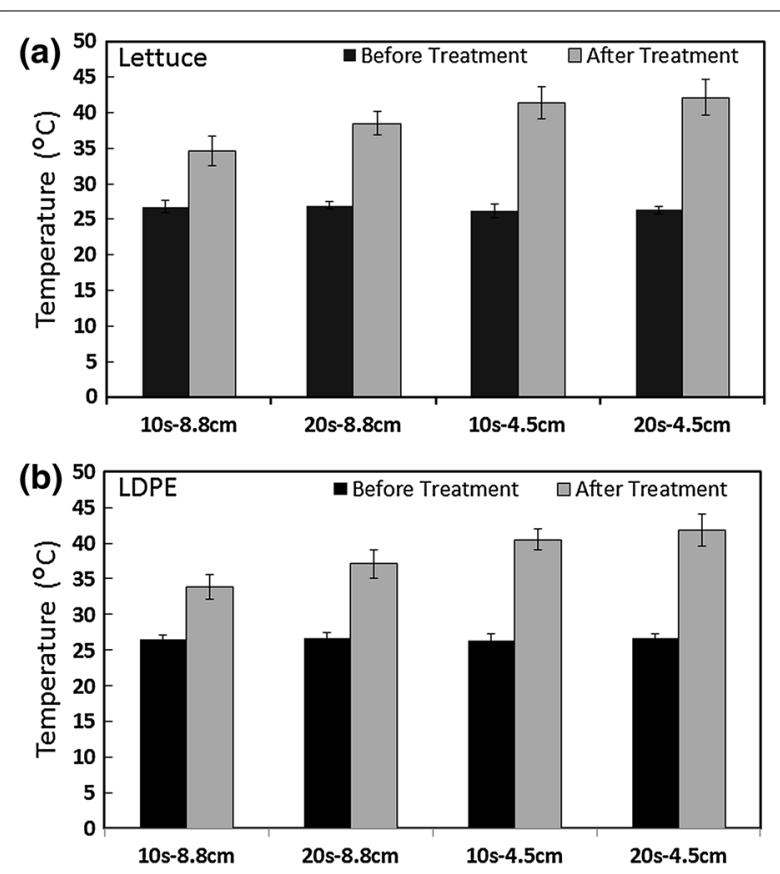

Figure 3 Surface temperature profile of lettuce and LDPE films after PUV treatment. The surface temperatures of lettuce leaves (a) and LDPE films (b) were measured at distances of 8.8 and $4.5 \mathrm{~cm}$ from the UV light source, before and after 20 or 10 s exposures. Values are presented as the mean \pm SE of two experiments performed in triplicate. Columns mean, bars SE.

administered for $10 \mathrm{~s}$ at a distance of $8.8 \mathrm{~cm}$, the highest surface temperature was found to be $34.6 \pm 2.1^{\circ} \mathrm{C}$ (for lettuce), and $33.9 \pm 1.7^{\circ} \mathrm{C}$ (for LDPE). These temperature data indicated that the PUV process resulted in some instant heat generation. It was also observed that with a longer exposure time and shorter treatment distance $(20 \mathrm{~s}-4.5 \mathrm{~cm})$ more heat was generated (as measured by the temperature data) than with a shorter exposure time and longer treatment distance $(10 \mathrm{~s}-8.8 \mathrm{~cm})$. Overall, the temperature increase as a result of PUV treatment was in the range of $\sim 7.4-$ $15.8^{\circ} \mathrm{C}$ across all the treatment conditions tested. The temperature data collected in the current study are well within the range of several previously reported studies $[8,38,53-58]$. The results of the current study, in conjunction with the previous studies mentioned above, indicate that the increase in temperature resulting from PUV treatment is dependent on several factors, such as distance from the UV source to the target sample, frequency and duration of pulses, energy levels or fluences, and food or target surface type. The results from previous studies indicated that a UV-source-to-sample distance of approximately $10 \mathrm{~cm}$ may be used to avoid excessive heating during PUV light treatments $[38,56$, 59].

\section{PUV light mediated damage of bacterial cells in biofilms}

The fate of E. coli O157:H7 and L. monocytogenes cells on lettuce and LDPE surfaces under the experimental conditions (PUV treatment, $20 \mathrm{~s}-8.8 \mathrm{~cm}$ and $20 \mathrm{~s}-4.5 \mathrm{~cm}$ ) were evaluated by scanning electron microscopy (SEM) (Figure $4 \mathrm{a}-\mathrm{l}$ ). The formation of biofilm-like structures (i.e., extracellular polymeric substance-mediated aggregate formation) by both pathogens on lettuce and LDPE surfaces was evident at $48 \mathrm{~h}$ post-inoculation, but not at 24 h. Niemira and Cooke (2010) reported similar findings of the time-dependent formation of biofilm-like structures of E. coli on lettuce and spinach leaves [33]. The micrographs of control cells at $48 \mathrm{~h}$ post-inoculation also depicted cell crowding (Figure $4 \mathrm{~d}-\mathrm{l}$ ), which is also indicative of nascent biofilm formation, as reported previously $[33,36]$. At the individual cell level, minor morphological changes were evident in PUV-treated bacterial cells compared with control cells (Figure 4a-l). The PUV-treated cells appeared to have increased roughness on their surfaces, showing some signs of shrinkage (Figure 4b, c, e, f, h, i, k, l). In a recent study, Ramos-Villarroel et al. (2012) reported significant damage of the PUV-treated cell membrane in microorganisms [51]. Alterations in the bacterial cell membrane resulting from PUV treatment were also reported in another recent study [60]. The initial electron micrograph findings from the current study may indicate possible alterations or damage of the bacterial cell membrane structure as a result of PUV treatment, confirming the findings of others [51, 61]. However, this morphological change, which may indicate alteration or damage of the bacterial cell wall and cell membrane structures, should be interpreted with care and may not solely be attributable to PUV, rather it may be a contributory factor along with DNA structural damage (thiamine dimer formation) contributing to cell injury and death [10]. To supplement our findings of electron microscopy experiments by fluorescence microscopy method, we recovered a subset of PUV treated cells $(20 \mathrm{~s}-8.8 \mathrm{~cm})$ from biofilms formed on lettuce leaf surfaces over a period of $48 \mathrm{~h}$. The extent of bacterial inactivation as a result of PUV treatment was evaluated by intake of fluorescence dyes, acridine orange (AO, green) and propidium iodide (PI, red). Figure 5 depicts fluorescence micrograph images of untreated (no PUV treatment) and PUV treated $(20 \mathrm{~s}-8.8 \mathrm{~cm})$ cells from lettuce. Visual observations reveal a significant higher number of dead (red) bacterial cells in PUV treatment group (Figure 5c, d) as compared to the control group (Figure $5 \mathrm{a}, \mathrm{b}$ ). It is evident that in PUV treated cells, the live cell population is higher for L. monocytogenes (Figure 5c) than E. coli O157:H7 (Figure 5d). The findings of fluorescence microscopy also confirms our selective plating and luminescence-based quantitative assay 


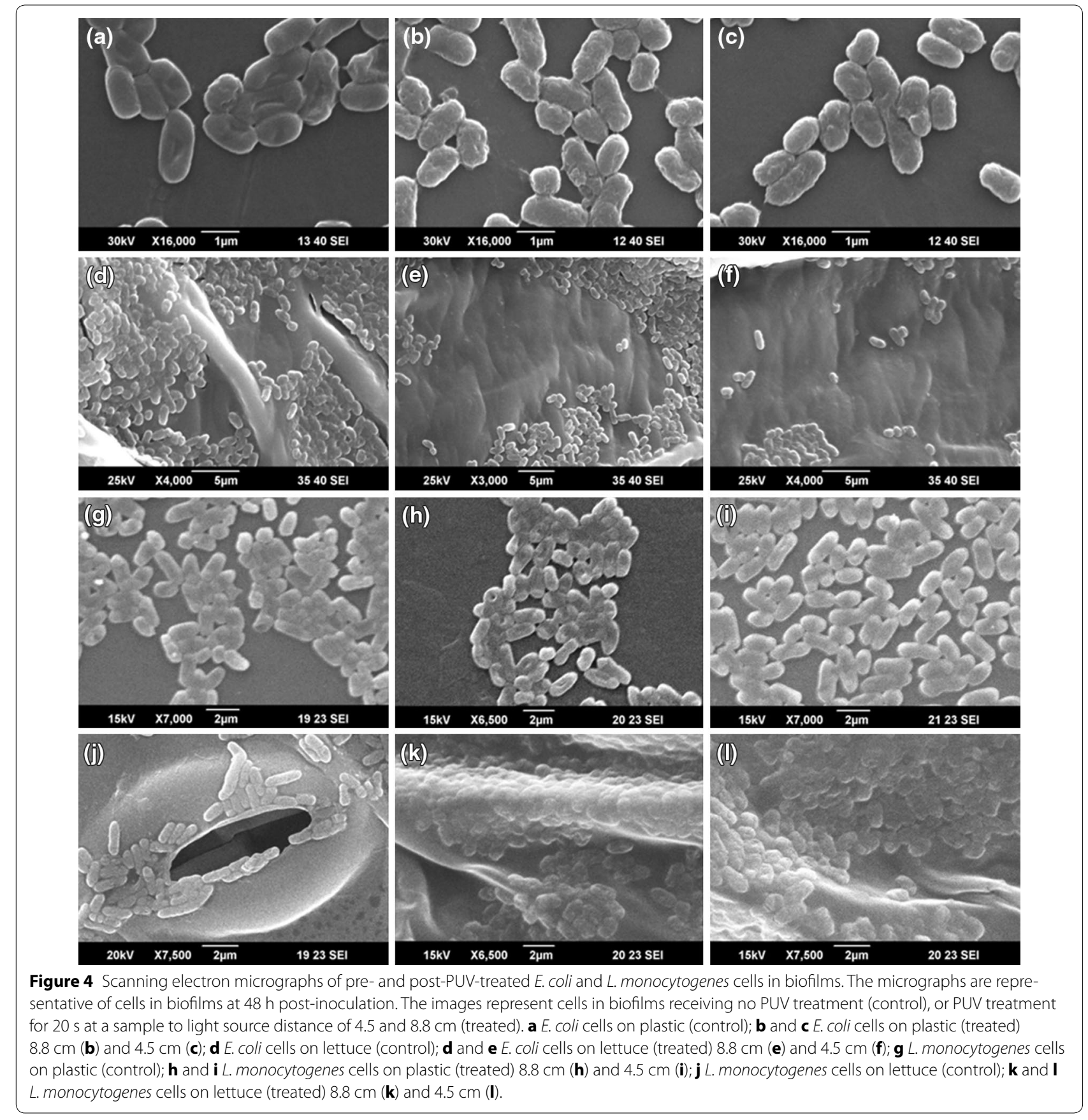

results indicating enhanced resistance of biofilm-forming Listeria (compared with E. coli) to PUV treatment.

\section{Conclusions}

The results from the current study indicate a moderate inhibitory effect of PUV treatment on LDPE food packaging material and Romaine lettuce surfaces harboring viable $E$. coli $\mathrm{O} 157: \mathrm{H} 7$ and $L$. monocytogenes cells in nascent biofilms. The PUV-mediated microbial inactivation values were found to range from approximately 0.6 $\log \mathrm{CFU} \mathrm{mL} \mathrm{mL}^{-1}$ to $4 \log \mathrm{CFU} \mathrm{mL} \mathrm{m}^{-1}$. Microbial inactivation due to PUV treatment was found to be dependent on several factors, including the PUV-treatment dosage, the microorganism type, and the type of material supporting the biofilm. In general, biofilms formed on the leaf surface showed less PUV-mediated inactivation compared with biofilms formed on LDPE film. The process generated nonsignificant amounts of heat, and can 

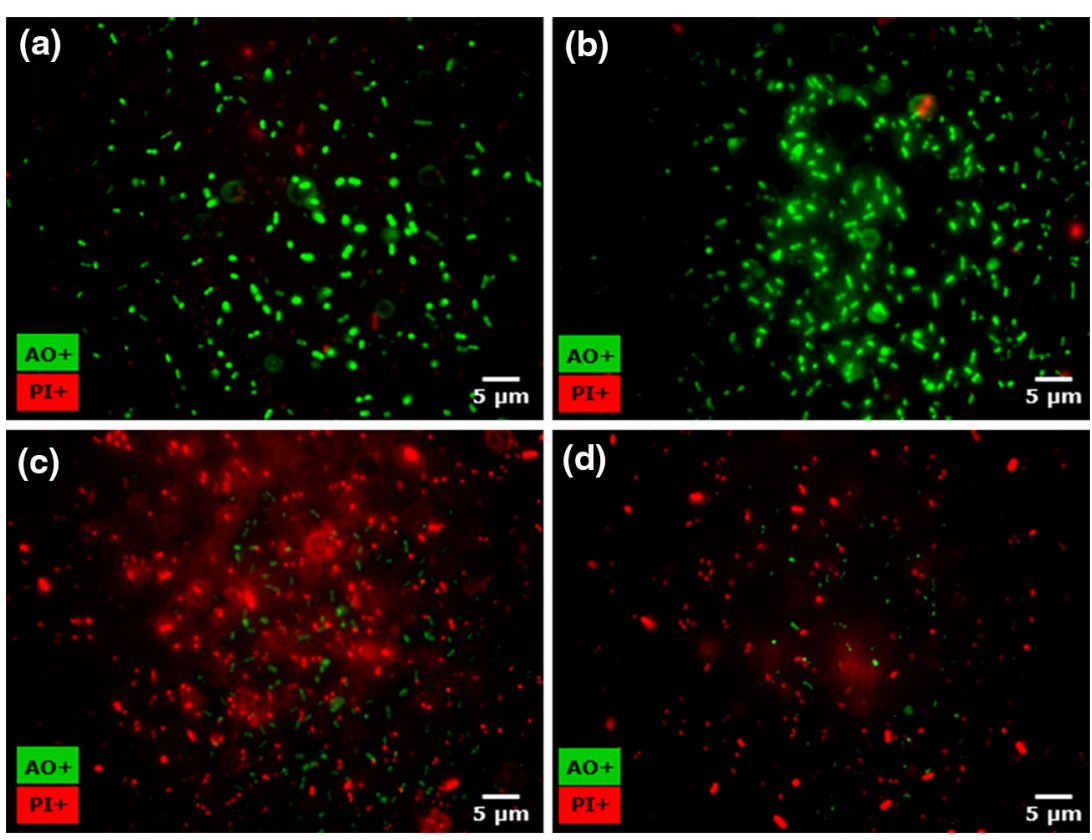

Figure 5 Fluorescence images of pre- and post-PUV-treated E. coli and L. monocytogenes cells in biofilms. The images represent cells in biofilms (48 h post-inoculation) receiving no PUV treatment (control), or PUV treatment for $20 \mathrm{~s}$ at a sample to light source distance of $8.8 \mathrm{~cm}$ (treated). The upper panels represent control cells of L. monocytogenes (a) and E. coli (b) recovered from lettuce. Lower panels depict the viability status of cells post-PUV treatment, L. monocytogenes (c) and E. coli (d) recovered from lettuce. Live or viable cells are represented by green fluorescence (AO+), while red fluorescence $(\mathrm{PI}+)$ indicates dead cells.

be considered as a nonthermal intervention method for reducing the microbial load in biofilms. This study provides preliminary evidence that PUV treatment can reduce the microbial load on produce and food packaging material surfaces, and therefore, in the future, this process may effectively be employed for surface decontamination of leafy produce and food contact areas.

\section{Methods}

Bacterial cultures, media, and growth conditions

E. coli O157:H7 strain EDL933 (ATCC 43895) and $L$. monocytogenes strain V7 $(1 / 2$ a) were obtained from the Food Microbiology Culture Collection at Alabama A\&M University. Both of these strains are associated with several foodborne outbreaks [62-64]. They are also known to produce firm biofilm structures, and contain all major virulence related genes $[65,66]$. The stock cultures were kept at $-80^{\circ} \mathrm{C}$ in $15 \%$ (vol/vol) glycerol for long-term storage. For routine propagation, cultures from the frozen stock were transferred to $10 \mathrm{~mL}$ of sterile brain-heart infusion (BHI) broth (Becton-Dickinson, Sparks, MD, USA), using a $0.1 \%$ ( $\mathrm{vol} / \mathrm{vol}$ ) inoculum, and incubated at $37^{\circ} \mathrm{C}$ overnight (referred hereafter as $\mathrm{ON}$ culture) prior to experimentation. The bacterial concentrations in the broth were adjusted by optical density (OD at $\left.600 \mathrm{~nm}, \mathrm{OD}_{600}\right)$, followed by plating and enumeration at appropriate dilutions. For biofilm assays, ON cultures were washed three times in PBS, diluted, and incubated at $30^{\circ} \mathrm{C}$ for different durations (h) [67]. For selective enumerations of E. coli $\mathrm{O} 157: \mathrm{H} 7$ and L. monocytogenes, sorbitol MacConkey agar supplemented with cefixime and tellurite, and modified Oxford agar were used, respectively (Becton-Dickinson).

\section{Biofilm formation in vitro}

One hundred microliters of the diluted (1:100) ON culture suspensions (in BHI) were added to polystyrene 96-well microplates (Corning, Lake Placid, NY, USA) incubated under static conditions at $30^{\circ} \mathrm{C}$ for 24 and $48 \mathrm{~h}$. Eight replicate wells for each microorganism were inoculated. After incubation, the excess medium was removed from the wells and one plate was used for confirmation of attachment and formation of biofilm using previously described crystal violet staining methods [31, 68] with some modifications. Briefly, plates were washed five times with PBS, then placed in a biosafety cabinet (BSC) for air drying (45 min) and $125 \mu \mathrm{L}$ of $0.1 \%$ solution of crystal violet in water was added to each well and incubated for $45 \mathrm{~min}$ at room temperature. Crystal violet was removed, and the plate was washed five times with PBS. After this step, the plates were air dried for 45 min inside a BSC laminar flow hood with continuous air circulation. Then, 
$125 \mu \mathrm{l}$ of $30 \%$ acetic acid in water was added to each well of the plate and mixed to dissolve the crystal violet dye. Measurement of biofilm formation in each well was performed by recording the $\mathrm{OD}$ at $550 \mathrm{~nm}\left(\mathrm{OD}_{550}\right)$ using $30 \%$ acetic acid in water as the blank. Alcian blue staining of biofilm-associated acidic polysaccharides (a major constituent of extracellular polymeric substances) was also performed, using a previously reported method [32], to confirm the crystal violet data.

\section{Preparation of produce and model food contact surface prototypes}

Whole heads of Romaine lettuce were purchased from a local supermarket 1-2 days after stocking, and were used on the same day. To maintain the uniformity among different samples purchased on different days, the brand of the product and the supermarket remained unchanged during the study. For each head of lettuce, the two outermost leaf layers were discarded. The inner leaves were aseptically removed, and were cut into $3 \times 3 \mathrm{~cm}$ pieces using sterile scissors. All pieces were stored in empty $100 \times 15 \mathrm{~mm}$ petri dishes (Fisher Scientific, Pittsburgh, PA, USA) with water-soaked Kimwipes ${ }^{\oplus}$ (sterilized) to preserve humidity. To generate a prototype food contact surface (to represent packaging), LDPE bags (2 MIL; Uline, Waukegan, MI, USA) were used. The LDPE bags were aseptically cut into $3 \times 3 \mathrm{~cm}$ pieces of film. The cut pieces were sterilized by wiping with $70 \%$ ethanol followed by air drying in a BSC and were used for inoculation.

\section{Inoculation of lettuce leaves and packaging films and recovery of attached cells}

The pieces of lettuce or packaging (LDPE) films were inoculated with $E$. coli O157:H7 or L. monocytogenes. The pieces were submerged in the bacterial suspension $\left(10^{4}\right.$ CFU mL $\mathrm{mL}^{-1}$ in BHI) in the wells of sterile 24-well plates (1 piece per well in $400 \mu \mathrm{l}$ suspension). Un-inoculated pieces were included in the study to verify the absence of target pathogens. The petri dish containing the leaf or LDPE film pieces were incubated at $30^{\circ} \mathrm{C}$ for 24 and $48 \mathrm{~h}$. The formation of biofilms was confirmed by the crystal violet staining method (as described in the earlier section) and by SEM (described in a later section). One replicate was dipped in $10 \mathrm{~mL}$ of saline for $3 \mathrm{~s}$ to remove residue. The physical detachment of bacteria from produce (or LDPE film) was conducted by a previously described method [31]. Each piece of lettuce leaf or LDPE film was transferred to a $50 \mathrm{~mL}$ tube containing $25 \mathrm{~mL}$ of PBS and vortexed for $20 \mathrm{~s}$ to remove loosely attached bacteria. To recover strongly bound cells, the same tubes were sonicated for $30 \mathrm{~s}$ at $50 \%$ power using a Fisher Scientific Sonic Dismembrator (Model 50), and $200 \mu$ lof the supernatant was diluted and plated on selective agar. Between each sonication, the sonicator probe was sterilized with $70 \%$ ethanol and rinsed with distilled water. For enumeration, selective agar plates were incubated for $24 \mathrm{~h}$ at $37^{\circ} \mathrm{C}$.

\section{Treatment with PUV light}

A laboratory-scale pulsed-light system (SteriPulseXL 3000, Xenon Corp., Wilmington, MA, USA) was used to administer PUV light. A detailed description and operating details of the PUV system can be found at the manufacturer's (Xenon) website and in previously published reports $[12,21,53]$. According to the manufacturer's specifications, the pulsed light system generated $1.27 \mathrm{~J} \mathrm{~cm}^{-2}$ per pulse of broadband energy $(200-1,100 \mathrm{~nm})$ at $7.6 \mathrm{~cm}$ below the central axis of the pulsed UV lamp. The energy distributions were approximately 54,26 , and $20 \%$ in the ultraviolet, visible, and infrared regions, respectively. The system produced three pulses per second with a width of $360 \mu \mathrm{s}$ for an input of $3,800 \mathrm{~V}[23,27,69]$. The pieces of lettuce and LDPE films were treated at two distances $(4.5$ and $8.8 \mathrm{~cm})$ from the UV light source, and were exposed to PUV light for two time durations (10 and $20 \mathrm{~s}$ ). Before and immediately after (within $5 \mathrm{~s}$ or less) each treatment, the surface temperature on the sample pieces was measured using an infrared thermometer (Fisher Scientific) [38].

\section{Microbiological analyses \\ Selective plating method}

After treatment, the attached cells from the samples (pieces of leaves or LDPE films) were recovered as described above. A $100 \mu \mathrm{l}$ aliquot of the appropriate dilution (in duplicate) of the vortexed and sonicated solution was plated on sorbitol MacConkey agar supplemented with cefixime and tellurite or modified Oxford agar (in triplicate for each dilution) for enumeration. The plates were incubated for $24 \mathrm{~h}$ at $37^{\circ} \mathrm{C}$. Appropriate controls were established by plating non-PUV treated lettuce leaves or LDPE film samples.

\section{Quantitative assay of microbial viability}

The effect of PUV treatment on the viability of the biofilm-forming microorganisms was evaluated using a BacTiter-Glo $^{\mathrm{TM}}$ Microbial Cell Viability Assay Kit (Promega, Madison, WI, USA) according to the manufacturer's instructions. Briefly, an aliquot of $100 \mu \mathrm{l}$ of bacterial cell suspension (dislodged from the leaf or LDPE surface) after PUV treatment of the bacterial samples were transferred to 96-well microtiter plates. An equal volume $(100 \mu \mathrm{l})$ of BacTiter-Glo ${ }^{\mathrm{m}}$ reagent was then added to the wells, the plates were mixed briefly on a shaker, and the luminescence was recorded using a microplate luminometer (BioTek Synergy HT, Winooski, VT, USA) for the 
quantitative enumeration of the live-dead status of bacterial cells upon PUV treatment. The data were expressed as RLU. ATP solutions of concentrations ranging from 0.1 to $100 \mathrm{nM}$ were used as internal controls to standardize all experiments. The RLU values of the supernatant of vortexed and sonicated lettuce leaves and LDPE piece samples (non-inoculated) were used to normalize inoculated sample RLU values.

\section{Fluorescence microscopy analysis}

Bacterial cell death as a result of PUV exposures were determined by using a fluorescence microscopy method described previously [70]. Briefly, a cell staining solution containing $20 \mu \mathrm{g} / \mathrm{mL}$ of acridine orange (AO) and $100 \mu \mathrm{g} / \mathrm{mL}$ propidium iodide (PI) (Sigma) were prepared in PBS. The bacterial cells (exposed to PUV, as described in previous sections) were dislodged from leaf surfaces by sonication and vortexing. A $100 \mu \mathrm{L}$ aliquots of cell suspension was mixed with $100 \mu \mathrm{L}$ of staining solution and analyzed immediately with a fluorescence microscope (Nikon Eclipse TS 100, with SPOT software, version 4.6.4.2, Diagnostic Instruments, Sterling Heights, MI, USA) using green (for AO) and red filters (for PI). The detection of live (L) and dead (D) cells were conducted in the following manner, green $(\mathrm{L})$ and red (D), both by visual scoring on a fixed microscopic field and by using image analysis software, SPOT, version 4.6.4.2 (images acquisition) and ImageJ v1.38 (NIH, USA) with "color counter" (v2001) and "color histogram" plug-ins (v2007) to analyze and enumerate the images.

\section{Scanning electron microscopic analysis}

For SEM analyses, the inoculated lettuce leaves and LDPE films were processed, mounted, and sputter-coated following a method reported by Niemira and Cooke [33]. The SEM images were acquired using a JEOL $6390 \mathrm{LV}$ electron microscope (JOEL, Tokyo, Japan) operating at voltages of $15-30 \mathrm{kV}$ in the high vacuum mode. The surfaces of the test materials (lettuce leaves and LDPE) were examined for the confirmation of typical sessile forms of bacterial aggregates with respect to the formation of biofilms, for both control and PUV-treatments at each post-inoculation time point. Two independent trials of SEM experiments (including sample preparations and imaging) were conducted.

\section{Statistical analysis}

The effect of PUV parameters (time and distance) on microbial destruction was investigated by two independent trials (performed in triplicate). Surviving microbial counts (viable count) were converted to $\log \mathrm{CFU} \mathrm{mL} \mathrm{m}^{-1}$. For each data point, the standard error of the mean (SE) was estimated, and data were expressed as the mean $\pm \mathrm{SE}$ (error bars in figures indicate SE estimates). The data for microbial counts were subjected to analysis of variance (ANOVA) and Tukey's test using SAS software (version 9.3, SAS Institute, Cary, NC, USA) for comparisons of microbial inhibition values between control and PUVexposed sample means. The limit for statistical significance was set at $P<0.05$.

\section{Authors' contributions}

NLM and PB designed the experiments, analyzed the data, and drafted the manuscript. NLM carried out the experiments. All authors read and approved the final manuscript.

\section{Author details}

${ }^{1}$ Department of Food and Animal Sciences, Alabama A\&M University, Huntsville, AL 35762, USA. ${ }^{2}$ Division of Epidemiology, Biostatistics, and Environmental Health Science, School of Public Health, The University of Memphis, Memphis, TN 38152, USA. ${ }^{3}$ Present Address: General Mills, Inc., Golden Valley, MN, USA.

\section{Acknowledgements}

This study was partly supported by USDA-NIFA (Grant Numbers: ALAX-0120210 and 2010-38821-21448), and by start-up funds from the University of Memphis. The authors thank Dr. Josh Herring for SEM analyses, Dr. Lamin Kassama and Dr. Peter Wambura for operation of the PUV equipment, and technical assistance.

\section{Compliance with ethical guidelines}

\section{Competing interests}

The authors declare that they have no competing interests.

Received: 8 May 2015 Accepted: 11 May 2015

Published online: 10 June 2015

\section{References}

1. Erickson MC, Webb CC, Diaz-Perez JC, Phatak SC, Silvoy JJ, Davey L et al (2010) Infrequent internalization of Escherichia coli O157:H7 into fieldgrown leafy greens. J Food Prot 73(3):500-506

2. Beuchat $L R$, Rhu JH (1997) Produce handling and processing practices. Emerg Infect Dis 3(4):459-465

3. Goodburn C, Wallace CA (2013) The microbiological efficacy of decontamination methodologies for fresh produce: a review. Food Control 32(2):418-427

4. Du J, Han Y, Linton RH (2002) Inactivation by chlorine dioxide gas (ClO2) of Listeria monocytogenes spotted onto different apple surfaces. Food Microbiol 19(5):481-490

5. Lu Z, Yu Z, Gao X, Zhang L (2005) Preservation effects of gamma irradiation on fresh-cut celery. J Food Eng 67(2):347-351

6. Orlowska M, Koutchma T, Grapperhaus M, Gallagher J, Schaefer R, Defelice C (2013) Continuous and pulsed ultraviolet light for nonthermal treatment of liquid foods. Part 1: effects on quality of fructose solution, apple juice, and milk. Food Bioprocess Technol 6(6):1580-1592

7. Nicorescu I, Nguyen B, Moreau-Ferret M, Agoulon A, Chevalier S, Orange N (2013) Pulsed light inactivation of Bacillus subtilis vegetative cells in suspensions and spices. Food Control 31(1):151-157

8. Rajkovic A, Tomasevic I, Smigic N, Uyttendaele M, Radovanovic R, Devlieghere F (2010) Pulsed UV light as an intervention strategy against Listeria monocytogenes and Escherichia coli $0157: \mathrm{H7}$ on the surface of a meat slicing knife. J Food Eng 100:446-451

9. Morey A, McKee SR, Dickson JS, Singh M (2010) Efficacy of ultraviolet light exposure against survival of Listeria monocytogenes on conveyor belts. Foodborne Pathog Dis 7(6):737-740

10. Koutchma T, Forney LJ, Moraru CI (2009) Ultraviolet light in food technology: principles and applications. CRC Press, Boca Raton 
11. Keklik NM, Demirci (2009) A pulsed UV-light: advantages for food decontamination. In: Resource, vol 16, 1995/12/01 edn. ASABE, St. Joseph, pp 18-19. doi:10.13031/2013.29318

12. Krishnamurthy K, Demirci A, Irudayaraj J (2008) Inactivation of Staphylococcus aureus in milk and milk foam by pulsed light treatment and surface response modeling. Trans ASABE 51(6):2083-2090

13. Krishnamurthy K, Demirci A, Irudayaraj JM (2007) Inactivation of Staphylococcus aureus in milk using flow-through pulsed UV-light treatment system. J Food Sci 72(7):M233-M239

14. Koutchma T, Forney LJ, Moraru CI (2009) Principles and applications of UV technology. In: Koutchma T, Forney LJ, Moraru Cl (eds) Ultraviolet light in food technology: principles and applications. CRC Press, Boca Raton, pp $1-31$

15. Uesugi AR, Moraru Cl (2009) Reduction of Listeria on ready-to-eat sausages after exposure to a combination of pulsed light and nisin. J Food Prot 72(2):347-353

16. Gomez-Lopez VM, Ragaert P, Debevere J, Devlieghere F (2007) Pulsed light for food decontamination: a review. Trends Food Sci Technol 18:464-473

17. Shriver S, Yang W, Chung S-Y, Percival S (2011) Pulsed ultraviolet light reduces immunoglobulin E binding to Atlantic white shrimp (Litopenaeus setiferus) extract. Int J Environ Res Public Health 8(7):2569-2583

18. Krishnamurthy K, Jun S, Tewari JC, Irudayaraj JM, Demirci (2007) A Investigation of Staphylococcus aureus inactivation by pulsed UV-light and infrared heating using microspectrometry and transmission electron microscopy. In: American Society of Agricultural and Biological Engineers Annual International Meeting, paper no 076027: June; Minneapolis, Minnesota, USA. ASABE, pp 1-12. doi:10.13031/2013.23300

19. Keklik NM, Demirci A, Puri VM (2009) Decontamination of chicken frankfurters with pulsed UV-light. In: American Society of Agricultural and Biological Engineers Annual International Meeting, paper no 095973: June; Reno, Nevada, USA. ASABE. doi:10.13031/2013.27011

20. Elmnasser N, Guillou S, Leroi F, Orange N, Bakhrouf A, Federighi M (2007) Pulsed-light system as a novel food decontamination technology: a review. Can J Microbiol 53(7):813-821

21. Xenon: SteriPulse-XL'RS-3000 Sterilization Systems. Xenon Corporation Sterilization and Decontamination Brochure 2009. http://www.xenoncorp.com/Literature/PDF/SteriPulse\%20Data\%20Sheet\%20Rev\%20J.pdf. Accessed 9 May 2014

22. Sauer A, Moraru CI (2009) Inactivation of Escherichia coli ATCC 25922 and Escherichia coli 0157:H7 in apple juice and apple cider, using pulsed light treatment. J Food Prot 72(5):937-944

23. Chung SY, Yang W, Krishnamurthy K (2008) Effects of pulsed UV-light on peanut allergens in extracts and liquid peanut butter. J Food Sci 73(5):C400-C404

24. Keklik NM, Demirci A, Patterson PH, Puri VM (2009) Decontamination of shelled eggs with pulsed UV-Light. In: American Society of Agricultural and Biological Engineers Annual International Meeting, paper no 095974 : June; Reno, Nevada, USA. ASABE, pp 1-10. doi:10.13031/2013.27012

25. Ganan M, Hierro E, Hospital XF, Barroso E, Fernandez M (2013) Use of pulsed light to increase the safety of ready-to-eat cured meat products. Food Control 32(2):512-517

26. Bialka KL, Demirci A (2007) Pulsed ultra-violet light decontamination of small fruits. In: American Society of Agricultural and Biological Engineers Annual International Meeting, paper no 076107: June; Minneapolis, Minnesota, USA. ASABE, pp 1-12. doi:10.13031/2013.23331

27. Bialka KL, Demirci A (2008) Decontamination of Escherichia coli O157:H7 and Salmonella Enterica on blueberries using ozone and pulsed UV-light. In: American Society of Agricultural and Biological Engineers Annual International Meeting, paper no 084511: June; Providence, Rhode Island, USA. ASABE, pp 1-15. doi:10.13031/2013.24876

28. Gomez-Lopez VM, Devlieghere F, Bonduelle V, Debevere J (2005) Intense light pulses decontamination of minimally processed vegetables and their shelf-life. Int J Food Microbiol 103(1):79-89

29. Li J, Hirota K, Yumoto H, Matsuo T, Miyake Y, Ichikawa T (2010) Enhanced germicidal effects of pulsed UV-LED irradiation on biofilms. J Appl Microbiol 109(6):2183-2190

30. Wang T, Macgregor SJ, Anderson JG, Woolsey GA (2005) Pulsed ultra-violet inactivation spectrum of Escherichia coli. Water Res 39(13):2921-2925

31. Patel J, Sharma M (2010) Difference in attachment of Salmonella enterica serovars to cabbage and lettuce leaves. Int J Food Microbiol 139:41-47
32. Rayner J, Veeh R, Flood J (2004) Prevalence of microbial biofilms on selected fresh produce and household surfaces. Int J Food Microbiol 95(1):29-39

33. Niemira BA, Cooke PH (2010) Escherichia coli O157:H7 biofilm formation on romaine lettuce and spinach leaf surfaces reduces efficacy of irradiation and sodium hypochlorite washes. J Food Sci 75(5):M270-M277

34. Elhariry HM (2011) Attachment strength and biofilm forming ability of Bacillus cereus on green-leafy vegetables: cabbage and lettuce. Food Microbiol 28(7):1266-1274

35. Nilsson RE, Ross T, Bowman JP (2011) Variability in biofilm production by Listeria monocytogenes correlated to strain origin and growth conditions. Int J Food Microbiol 150(1):14-24

36. Ölmez H, Temur SD (2010) Effects of different sanitizing treatments on biofilms and attachment of Escherichia coli and Listeria monocytogenes on green leaf lettuce. LWT Food Sci Technol 43(6):964-970

37. Bernbom N, Vogel BF, Gram L (2011) Listeria monocytogenes survival of UV-C radiation is enhanced by presence of sodium chloride, organic food material and by bacterial biofilm formation. Int J Food Microbiol 147(1):69-73

38. Ringus DL, Moraru Cl (2013) Pulsed Light inactivation of Listeria innocua on food packaging materials of different surface roughness and reflectivity. J Food Eng 114(3):331-337

39. Hingston PA, Stea EC, Knochel S, Hansen T (2013) Role of initial contamination levels, biofilm maturity and presence of salt and fat on desiccation survival of Listeria monocytogenes on stainless steel surfaces. Food Microbiol 36(1):46-56

40. Ray B, Sandine WE (1992) Food biopreservatives and microbial origin. CRC Press Inc, Boca Raton

41. Birmpa A, Vantarakis A, Paparrodopoulos S, Whyte P, Lyng J (2014) Efficacy of three light technologies for reducing microbial populations in liquid suspensions. Biomed Res Int 2014:673939

42. Akbas MY, Ölmez H (2007) Inactivation of Escherichia coli and Listeria monocytogenes on iceberg lettuce by dip wash treatments with organic acids. Lett Appl Microbiol 44(6):619-624

43. Mu H, Zhang A, Zhang L, Niu H, Duan J (2014) Inhibitory effects of chitosan in combination with antibiotics on Listeria monocytogenes biofilm. Food Control 38:215-220

44. Simões M, Simões LC, Vieira MJ (2010) A review of current and emergent biofilm control strategies. LWT Food Sci Technol 43(4):573-583

45. Taraszkiewicz A, Fila G, Grinholc M, Nakonieczna J (2012) Innovative strategies to overcome biofilm resistance. Biomed Res Int 2013:150653

46. Dourou D, Beauchamp CS, Yoon Y, Geornaras I, Belk KE, Smith GC et al (2011) Attachment and biofilm formation by Escherichia coli O157:H7 at different temperatures, on various food-contact surfaces encountered in beef processing. Int J Food Microbiol 149(3):262-268

47. Ells TC, Truelstrup Hansen $L$ (2006) Strain and growth temperature influence Listeria spp. attachment to intact and cut cabbage. Int J Food Microbiol 111(1):34-42

48. Kadam SR, den Besten HM, van der Veen S, Zwietering MH, Moezelaar $\mathrm{R}$, Abee T (2013) Diversity assessment of Listeria monocytogenes biofilm formation: impact of growth condition, serotype and strain origin. Int J Food Microbiol 165(3):259-264

49. Chae MS, Schraft H (2000) Comparative evaluation of adhesion and biofilm formation of different Listeria monocytogenes strains. Int J Food Microbiol 62(1-2):103-111

50. Ban GH, Park SH, Kim SO, Ryu S, Kang DH (2012) Synergistic effect of steam and lactic acid against Escherichia coli O157:H7, Salmonella Typhimurium, and Listeria monocytogenes biofilms on polyvinyl chloride and stainless steel. Int J Food Microbiol 157(2):218-223

51. Ramos-Villarroel AY, Aron-Maftei N, Martín-Belloso O, Soliva-Fortuny R (2012) The role of pulsed light spectral distribution in the inactivation of Escherichia coli and Listeria innocua on fresh-cut mushrooms. Food Control 24(1-2):206-213

52. Schleifer KH, Kandler O (1972) Peptidoglycan types of bacterial cell walls and their taxonomic implications. Bacteriol Rev 36(4):407-477

53. Bialka KL, Demirci A (2008) Efficacy of pulsed UV-light for the decontamination of Escherichia coli O157:H7 and Salmonella spp. on raspberries and strawberries. J Food Sci 73:M201-M207

54. Keklik NM, Demirci A, Bock RG (2011) Decontamination of whole chicken carcass by using a pilot scale pulsed UV-light system. Trans ASABE 54(3):993-1000 
55. Wambura P, Verghese M (2011) Effect of pulsed ultraviolet light on quality of sliced ham. LWT Food Sci Technol 44(10):2173-2179

56. Luksiene Z, Buchovec I, Kairyte K, Paskeviciute E, Viskelis P (2012) Highpower pulsed light for microbial decontamination of some fruits and vegetables with different surfaces. J Food Agric Environ 10(3\&4):162-167

57. Keklik NM, Demirci A, Puri VM (2009) Inactivation of Listeria monocytogenes on unpackaged and vacuum-packaged chicken frankfurters using pulsed UV-light. J Food Sci 74(8):M431-M439

58. Krishnamurthy K, Demirci A, Irudayaraj J (2004) Inactivation of Staphylococcus aureus by pulsed UV-light sterilization. J Food Prot 67(5):1027-1030

59. Schenk M, Guerrero S, Alzamora SM (2008) Response of some microorganisms to ultraviolet treatment on fresh-cut pear. Food Bioprocess Technol 1(4):384-392

60. Kramer B, Muranyi P (2013) Effect of Pulsed Light on structural and physiological properties of Listeria innocua and Escherichia coli. J Appl Microbiol 116(3):596-611

61. Schenk M, Raffellini S, Guerrero S, Blanco GA, Alzamora SM (2011) Inactivation of Escherichia coli, Listeria innocua and Saccharomyces cerevisiae by UV-C light: study of cell injury by flow cytometry. LWT Food Sci Technol 44(1):191-198

62. Fleming DW, Cochi SL, MacDonald KL, Brondum J, Hayes PS, Plikaytis BD et al (1985) Pasteurized milk as a vehicle of infection in an outbreak of listeriosis. N Engl J Med 312(7):404-407

63. He W, Luchansky JB (1997) Construction of the temperature-sensitive vectors pLUCH80 and pLUCH88 for delivery of Tn917:Notl/Smal and use of these vectors to derive a circular map of Listeria monocytogenes Scott A, a serotype 4b isolate. Appl Environ Microbiol 63(9):3480-3487

64. Wells JG, Davis BR, Wachsmuth IK, Riley LW, Remis RS, Sokolow R et al (1983) Laboratory investigation of hemorrhagic colitis outbreaks associated with a rare Escherichia coli serotype. J Clin Microbiol 18(3):512-520

65. Marsh EJ, Luo H, Wang H (2003) A three-tiered approach to differentiate Listeria monocytogenes biofilm-forming abilities. FEMS Microbiol Lett 228(2):203-210

66. Lee JH, Kim YG, Cho MH, Wood TK, Lee J (2011) Transcriptomic analysis for genetic mechanisms of the factors related to biofilm formation in Escherichia coli 0157:H7. Curr Microbiol 62(4):1321-1330

67. Borucki MK, Peppin JD, White D, Loge F, Call DR (2003) Variation in biofilm formation among strains of Listeria monocytogenes. Appl Environ Microbiol 69(12):7336-7342

68. O'Toole GA (2011) Microtiter dish biofilm formation assay. J Vis Exp 30(47):2437

69. Keklik NM, Demirci A, Puri VM (2008) Modeling the inactivation of Escherichia coli O157:H7 and Salmonella enterica on raspberries and strawberries resulting from exposure to ozone or pulsed UV-light. J Food Eng 85:444-449

70. Banerjee P, Lenz D, Robinson JP, Rickus JL, Bhunia AK (2008) A novel and simple cell-based detection system with a collagen-encapsulated B-lymphocyte cell line as a biosensor for rapid detection of pathogens and toxins. Lab Invest 88(2):196-206

\section{Submit your next manuscript to BioMed Central and take full advantage of:}

- Convenient online submission

- Thorough peer review

- No space constraints or color figure charges

- Immediate publication on acceptance

- Inclusion in PubMed, CAS, Scopus and Google Scholar

- Research which is freely available for redistribution

Submit your manuscript at

www.biomedcentral.com/submit

C BioMed Central 